rocks of the central platean of France, through Carboniferous, Triassic, Jurassic and Cretaceous strata. 'The last mentioned are chiefly limestones, nearly horizontal, presenting steep and often high cliffs, either washed by the river, or bordering its broader and older valley. The softer bands of limestone have been hollowed out along the valley by frost and water, and here and there present recesses and caves. These, in several instances, have been artificially enlarged, and in very many cases have afforded shelter to pre-historic people, and still retain heaps of bones and hearth-stuff, with flint implements of numerous kinds, carved bones, antlers, and occasionally human bones. The most common bones and antlers are those of the Reindeer, which must have abounded in Southern France, whether remaining all the year round, or migrating from plain to mountain and back again in their season, for the cave-folk killed them of all ages in vast numbers. The cold climate necessary for the Reindeer has long passed away; the Musk Ox and the Hairy Mammoth disappeared also with the Reindeer; and, looking at the great changes in geographical outlines and contours that have taken place since the extinction of the European Mammoth, the author thought that some eight or nine thousand years would not be too long for the bringing about of such changes. That the old Cave-folk of Perigord saw the living Mammoth, a lively outline-sketch of its peculiar and shaggy form on a piece of ivory. found in the Madelaine Cave, is satisf ctory evidence. The special geology of the district, the characters of the several cares and their contents, and the most striking of the implements of stone and bone, were described in this paper; the human remains found at Cro-Magnon, a gigantic chief and his more ordinary companions, were specially treated of ; and the high probability of their belonging to the same race of men as the older Cave-folk was discussed at some length.

\title{
CORRESPOITIEITCE.
}

\section{THE LOWER SCROBICULARIA AND LOWER CYCLAS CLAYS OF THE MERSEY AND RIBBLE.'}

Sir,-On the 14th of Nov., 1871, Mr. T. M. Reade read a paper at the Geological Society of Liverpool, "On the Geology and Physics of the Post-Glacial Period," of which an abstract was given in Nature of December 28 (vol. v., p. 175), and a réchauffé by $\mathbf{M r}$. Reade in the Grol. MaG. for March, 1872 (Vol. IX., p. 111), in which month my "Explanation of Map 90 N.E." was published, which contains a description of Lower Scrobicularia Clay at Crossens, in Lancashire; from which it will be seen that it is impossible for me to have first learned of such a clay in that county from Mr. Reade's papers, as he suggests, as no reference is made to it in the Abstract in Nature, and my "Explanation" was then in the press, which latter was written from notes made previously to my leaving South-west Lancashire, in December, 1868. And in point of fact, I never saw his paper until the present year, he not having favoured me with a reprint, in return for those of my own (sent at his request), and for replies to his letters asking for information.

Mr. Reade charges me with inaccuracy, because certain thin clays, with Scrobicularia, one to twenty feet in thickness, never cropping to the surface, and overlaid by from ten to seventy feet of still newer deposits, which he has discovered in his draining operations, near the coast (carried out since I left the district), are not shown on the maps. I reply that, even were the 'Lower Scrobicularia Clay' a surface-soil, it could not be separated from the 'Lower Cyclas Clay,'

1 This correspondence must now terminate-ED. Gror. Maq. 
with which it is intercalated, and which it apparently sometimes entirely replaces, the two deposits being lithologically one, any division between them would be a zoological boundary.

I am not surprised to hear of Mr. Reade's discovery of marine shells in a hole in the lower part of the grey clay, beneath the peat of Alt mouth, as I showed in my paper read at the Geol. Soc. of London, June, 1870, that beneath the peat and grey clay there is almost always a bed of Post-tertiary marine (Shirdley Hill) sand resting on denuded Boulder-Clay. But the upper part of the grey clay there I know to be of freshwater origin, containing rushes and other plants, as well as freshwater shells, which, however, are by no means common.

Freshwater shells also occur in the grey clay, beneath the peat, at the brick-pit, near the Isle of Wight, Birkdale, which I constantly visited during my nine months' stay at Birkdale, never finding any marine forms in it, though they occur abundantly in the silty-clay above the peat, and fragments of sea-shells were found in the Shirdley Hill Sand, underlying the grey clay of this pit.

The sand was absent in the Journal of the boring made at the Palace Hotel, Birkdale Park, communicated to me in 1868, by Mr. Holbrook Gaskell, J.P., the chairman of the Company, the peat and grey clay together having thinned to 18 inches, and being overlaid by 79 feet of modern sand, partly blown.

I would remind Mr. Reade that the peat overlaps the grey clays, and rests on marine sand and Boulder-clay, and that these clays have therefore nothing like an area- of 75 square miles, as he states. And that, again, this plain is only a portion of a larger one, since destroyed, in which the waters of the Mersey and Ribble met, not the brooks now draining into the 75 square miles.

H.M. Geotogicat Sorvey, Chardes i. Di Ranor. AMbLeswe.

\section{OEITUARY.}

ON the 24th of April died Mary Elizabeth, the wife of Sir Charles Lyell, Bart., in the 65th year of her age. Lady Lyell was the eldest daughter of Leonard Horner, Esq., F.R.S., a prominent member of the Geological Society from its foundation down to his death in 1864. In 1832 she was married to Sir Charles, then Mr. Lyell, and ever since constantly accompanied him in his several geological visits to North America, as well as on almost all his journeys on the Continent of Europe as well as in England. Lady Lyell entered warmly into the scientific pursuits of her husband, and keenly appreciated the continual changes and advances in geological knowledge. By her energetic assistance in writing from dictation, the labour of bringing out the several editions of the works on Geology, by Sir Charles Lyell, was materially lessened; and scarcely a proof-sheet was finally sent off to the printer without being first submitted to her for criticism and approval. In this way one of the last acts of her life was to read over the concluding chapter of the fourth edition of the "Antiquity of Man," just published. 